Lorenzo Cappellari, Claudio Lucifora and Dario Pozzoli

\title{
Determinants of Grades in Maths for Students in Economics
}

Department of Economics 


\title{
Determinants of Grades in Maths for Students in Economics.
}

\author{
Lorenzo Cappellari* \\ Catholic University of Milan \\ Claudio Lucifora ${ }^{\dagger}$ \\ Catholic University of Milan \\ Dario Pozzoli \\ Aarhus School of Business, Aarhus University
}

November 3, 2009

\begin{abstract}
This paper investigates the determinants of grades achieved in mathematics by first-year students in Economics. We use individual administrative data from 1993 to 2005 to fit an educational production function. Our main findings suggest that good secondary school achievements and the type of school attended are significantly associated with maths grades. Ceteris paribus, females typically do better than males. Since students can postpone the exam or repeat it when they fail, we also analyze the determinants of the elapsed time to pass the exam using survival analysis. Modeling simultaneously maths grades and the hazard of passing the exam, we find that the overall hazard rate of passing the exam is higher for those students who get the higher grades. The longer students wait to take the exam, the less likely they are to obtain high grades.
\end{abstract}

JEL classification: I21, I23, C50.

Keywords: maths grades, quantile regression, survival analysis.

\footnotetext{
${ }^{*}$ Corresponding Author. Address: Catholic University of Milan, Largo A. Gemelli 1, 20123 Milan, Italy. E-mail: lorenzo.cappellari@unicatt.it.

${ }^{\dagger}$ Address: Catholic University of Milan, Largo A. Gemelli 1, 20123 Milan, Italy. E-mail: claudio.lucifora@unicatt.it.

$¥$ Aarhus School of Business, Aarhus University, Department of Economics, Frichshuset, Hermodsvej 22, DK-8230 Aabyhoj, Denmark. E-mail: dpozzoli@asb.dk
} 


\section{Introduction}

Renewed emphasis is being placed by governments and employers on numeracy skills for all people to enhance their employability, job satisfaction, level of remuneration, community participation and social well-being. Recent OECD research (2005) has indicated that raising a country literacy and numeracy score by 1 per cent leads to a raise in productivity of 2.5 per cent with the flow-on increase of 1.5 per cent in GDP. Recent studies show that numeracy skills influence labour market performance and income in specific ways other than educational attainment (Charette and Meng, 1998; McIntosh and Vignoles, 2001). Proficiency in quantitative skills has been observed to improve job performance due not only to the array of computational tasks that are routinely performed in most jobs, but also because of the greater general productivity associated with quantitative literacy (Bishop, 1989; Murnane 1988; Ma, 2001). Rivera-Batiz (1992) found that quantitative literacy skills are a major factor raising the likelihood of full-time employment. Previous research also suggests that cognitive skills proficiency including adult numeracy are strongly and positively related with educational achievements (Kirsch et al., 1993; Tuijnman and Boudard, 2000; Desjardins, 2004). A recent OECD research (2000), using the Adult Literacy and Life Skills (ALL) Survey, indicates that higher average proficiency scores are associated with higher levels of educational attainment in all countries considered. More specifically, McNabb et al. (2002) and Smith and Naylor (2001) have found that grades obtained in the first-year mathematics exam can be a good predictor of the subsequent academic performance of students in Economics. Given the importance of numeracy skills widely documented in the economics literature, we decide to investigate their main determinants at the university level.

This paper, in particular, is concerned with the factors that determine individual success in the first-year mathematics exam for students in Economics. There is a 
substantial international literature that investigates the determinants of success in firstyear college courses, using student level data. A number of previous works both for the US and for the UK (Sabot and Linn, 1991; Durden and Ellis, 1995; Hanushek, 1995; Anderson et al., 1994; King, 1999; Cohn et al., 1999) document that the most important determinants of the academic achievements in first-year courses are prior qualifications, gender, age, family background and to some extent also the course attendance. The academic performance has been extensively researched also in Italian empirical works. Checchi et al. (2000) show that students' performance is positively correlated with family income and take this result as supporting the idea of family networking: students from richer families tend to go quicker because they have better prospects when they exit university. Cappellari (2004) studies the relationship between the type of high school attended and indicators of subsequent performance. He finds that general high schools increase the probability of transition to university and improve performance once at university. He also shows that private high schools are associated with lower academic performance, suggesting the higher quality of education provided by state schools. Finally, Bratti et al. (2006) investigate the effects of recent university reforms ${ }^{1}$ on academic performance. They find that, in Mathematics and Economics courses, the reform produced a reduction in the likelihood of failing the exams and an increase in the probability of passing them in the first year. They observe that the last two effects are directly produced by the reduced workload and simplification of the courses, since the average grades do not increase in such courses after the reform. We will not consider the role of this structural reform, because the evaluation of its effects on maths grades is behind the scope of this analysis.

Recently, Dolado and Morales (2006) have analyzed the determinants of grades

\footnotetext{
${ }^{1}$ In 2001 a "3+2" (unitary two tier) university reform system was introduced in Italy where a 3-year First Level degree followed by a 2-year Second Level degree replaced a one-tier system where the old degree (Laurea) institutional duration varied between a minimum of four (economics, for example) and a maximum of six years.
} 
in an introductory course of maths by first-year Economics undergraduate students at Universidad Carlos III, Madrid, over the period 2001-2005. Their main findings suggest that students with a technical specialization at high school tend to do better than those who attended a social sciences degree, controlling for pre-college skills through university entry-exam scores. By means of quantile regressions, they also find that students from state schools with a (non) technical degree are predominant in the upper (lower) parts of the grade distribution and that females tend to perform better than males. Their empirical analysis is, however, based on a sample which is limited both in terms of the variables included as controls and with respect to the number of academic years.

As we have already mentioned, also in this study we analyze the students' performance in maths. The aim of this paper is twofold. On the one hand, we will shed some light on the main factors associated with maths grades fitting an educational production function. On the other hand, we analyze the determinants of the elapsed time to pass the exam through a survival analysis. The latter objective is primarily related to the the didactic organization of Italian universities. This organization determines that students are free to choose whether to attend lectures and classes or not and when to sit exams. Courses are usually assessed at the end of the teaching periods and exams can be repeated without limitations in multiple alternative sessions during the same year or the following academic years. Students can refuse a grade in case they are not satisfied with their performance in a specific exam and attempt the exam in subsequent sessions. Exam failures are not registered in the students' records and there are no constraints on the number of exams to be passed in order to enroll in the following year. Another important feature of the Italian university is that even though the secondary school system is stratified into academic and vocational schools ${ }^{2}$, there is no formal

\footnotetext{
${ }^{2}$ The Italian secondary consists of four types of high schools: licei (General high schools), istituti tecnici (Professional high schools), istituti professionali (Vocational high schools) and finally scuole magistrali and istituti artistici (Teaching and Art schools). The first type of school lasts five years
} 
selection procedure at the enrollment and no limitation exists in relation to ability or the type of education acquired at secondary level. This may cause great heterogeneity of university students' ability especially in the first academic years. In this situation we could observe, on the one hand, the most able students passing the maths exam immediately and with good grades and, on the other hand, their peers coming from vocational tracks who need to put more effort and to study longer in order to enter the tournament and pass the minimum required numeracy ability threshold. But students who take longer could also be those who deliver a very low effort and repeat the exam several times until they get the minimum required maths ability threshold to pass the exam.

This "mass" tertiary education system implies considerable costs for demanders of such a service. For students wasted time is associated with the unsatisfactory experiences of failure and the consequent decision of interrupting university studies or of failure and repetition of the exam without limitations, the latter prolonging the time to graduation. The importance of these two problems is particularly evident in Italy. Dropout rates are very high during the first years of degree courses: in the academic year, $20 \%$ of first-year students did not renew their enrollment in the second year. ${ }^{3}$ The Italian university dropout rates are also the highest among the European countries. ${ }^{4}$ Furthermore, the Italian higher education system has always been characterized by an actual time of graduation much longer than in most other developed countries. The gap between actual and legal degree duration is partly due to the high percentage of and provides its graduates with general and academic skills useful for higher education. The second and third types are generally five-year studies and provide their students with professional skills that can be exploited in the labour market immediately after graduation. However, graduates from either Professional or Vocational high schools are allowed to enroll at the university if they choose to go on to further education. The fourth type, typically for those students who want to become teachers, lasts four years plus an additional year for those students who wish to go to university. So students from any of these tracks are formally entitled to enroll at university, conditional on having attended 5 years of secondary school

${ }^{3}$ Source: Miur Cnvsu (2005).

${ }^{4}$ OECD student survival rates in 2000 are lowest for Italy $(42 \%)$ compared to an OECD average of $70 \%$. 
inactive students, i.e. those who did not pass any exam during a given academic year. ${ }^{5}$

All these characteristics of the Italian university system explain why it is so important to consider both the grades achieved and the speed at which a student undertakes the exam to analyze individual academic performance. Previous research (Checchi et al., 2000) on this topic combined the two dimensions in one indicator. We prefer to consider them separately using two different econometric approaches. Given that data requirements are very demanding especially for duration analyses, we analyze students' performance in maths using a very informative and large sample covering 10 years, drawn from the administrative database of Cattolica University. ${ }^{6}$ One important advantage of this dataset is that the materials (contents, subjects and books) covered over the sample period and the way the exam is structured remain almost identical. Moreover, the different lecturers of maths courses have always been working in close collaboration with each other in order to coordinate their teaching and assessment activities. $^{7}$

The main results of this "case" study indicate that final high school grades and the type of high school attended are significantly correlated with maths grades and that females, ceteris paribus, typically do better than males. We also find that the students who pass the exam in the first year have higher grades than students who pass it from the third year on. Finally, the longer students wait to take the exam, the less likely they are to obtain high grades, confirming the idea that the most able students are more likely to pass the exam immediately and with good grades compared with their less able peers who need to study longer in order to pass the minimum required maths ability threshold.

\footnotetext{
${ }^{5}$ According to Miur Cnvsu (2005), in the academic year 1999/2000 23\% of Italian students were inactive.

${ }^{6}$ This is a very large private Italian college which offers undergraduate and graduate degrees in several subject areas, namely education, law, economics, the humanities, languages, maths, banking science and political science.

${ }^{7}$ We are particularly indebted with Anna Torriero for helpful discussions on the didactic organization of maths courses over the period considered.
} 
The structure of the paper is as follows. Section two describes the dataset and the estimation sample. In section three, we present the methodology used in this paper and the results of the empirical analysis. Section four concludes.

\section{Data}

We use a specific dataset to examine the performance of university students in terms of first-year maths grades. Data are drawn from the administrative records of Cattolica University. In this analysis, we focus on Economics students enrolled or with a completed degree from the academic year $1992 / 93$ to $2005 / 2006 .^{8}$

The dataset provides the following information: i) administrative information collected at enrollment (age, gender, region of residence, previous education); ii) information on academic career (faculty and grades and date of every exam); iii) all information collected to calculate the university fee (family income; if the student is a full-time worker; number of family components; paid fees).

From the original sample, we excluded individuals who declared to work full-time as well as individuals for whom we miss data either on personal characteristic or on family income. The resulting sample consists of almost 11,000 students.

Grades in the Italian education system are numerical, ranging from 18 to 31 over 30. ${ }^{9}$ As we mentioned in the introduction, Italian students are not obliged to take exams at the end of courses: they can take them in some fixed periods of the year throughout the duration of the degree course. From Table ??, we can see that the percentage of students who passed the exam in the first year decreases till the academic year 1995/96 and increases thereafter, especially after the academic year 2001/2002. As Bratti et al. (2006) argue, this could be related to the fact that the university

\footnotetext{
${ }^{8}$ Students who passed the math exam and dropped out later are retained in the sample.

${ }^{9}$ It is possible to pass an exam with the grades "30 cum laude": we coded this outcome as 31.
} 
reform implemented in 2001 tends to simplify university courses and not to an increase in the student academic ability, as the mean of final high school grades of enrolled students has not changed significantly in the period considered.

Table ?? reports the distribution of students used in the sample according to their maths grades. Most students (70\%) show grades up to 24 over 31 while about $10 \%$ show full grades (28-31 over 31 ). An analysis by gender indicates that women obtain the highest grades.

The definitions of variables used in the analysis are reported in Table ?? along with their sample means. Concerning the variables the following clarifications should be made. As indicator of pre-college performance we used the variable "final high school grades" This variable is strongly correlated with maths grades: Table ?? shows that students with the lowest final grades are more likely to come out badly in the math exam. The other way around, if we consider students with the highest final grades. High school types have been regrouped into 3 different categories (General, Professional/Vocational, Other) and we take into account whether they are private or state institutions. Tables ?? and ?? indicate that also high school types seem to be correlated with academic performance. The dummy variables "first year" and "second year" are equal to 1 if the student passed maths exam in the first and in the second academic year, respectively. From Table ??, we can see that on average only $59 \%$ of students pass the exam in the first academic year, suggesting that a consistent fraction of students takes a lot of time to pass maths exam. Finally, we decided to use the precise year, ranging from 1993 to 2006, in which students take and pass the exams rather than the first academic year of enrollment as a time fixed effect because, as previously mentioned, students can take the exam in some fixed periods of the year throughout the duration of the degree course. We finally include among the covariates a dummy variable related to whether the maths exam is a prerequisite to pass other 
exams. ${ }^{10}$

\section{$3 \quad$ Empirical strategy and main results}

\subsection{The determinants of mathematics skills among university students}

Following Hanushek (1995) Case and Deaton (1999), Dolado and Morales (2006) and Bratti and Staffolani (2002), we analyze student performance using educational production function approach, according to which maths grades are assumed to be a function of several inputs such as:

$$
G_{m}=g(X, A, Y, T, P)
$$

where $G_{m}$ represents maths grades (ranging from 18 to 31 ), $\mathrm{X}$ is a vector of personal characteristics including gender (reference category: females) and cohort dummies (reference category: students born after $1980^{11}$ ); A contains all information on previous education, such as high school type (reference category: other high school), whether the high school is a state institution, final high school grades, whether the high school is located in the North of Italy (reference category: high school located in a central or southern region) ; Y includes the dummy variables "first year" and "second year" relating to whether the student passed the exam in the first or second year of her academic career (reference category: the student passed the exam from the third year on),

\footnotetext{
${ }^{10}$ Until the academic year 1994/1995, if a student did not pass the most fundamental exams of the first year, including the maths exam, he could not enroll at the second year. For those students enrolled from the academic year 1995/1996 onwards, this is no longer the case.

${ }^{11}$ Year of birth has been grouped into the following cohorts: born before 1974, born between 1974 and 1979 and born after 1979.
} 
$\mathrm{T}$ are time fixed effects capturing the exact year in which the student passed the exam which is not necessarily the first year of enrollment (reference category: academic year $1992 / 1993)$ and $\mathrm{P}$ is a dummy variable related to whether maths exam is a prerequisite to pass other exams.

Table ?? reports the OLS estimates of equation (1) with heteroskedasticity-robust standard errors ${ }^{12}$. One of the strongest effects comes from high school type: graduates from General high schools (licei) have almost 1 extra point in maths exam compared to those from other high schools. In column two of Table ??, we also report the effect of General high schools in case it is distinguished into "Scientific" (licei scientifici) and "Humanities" (licei classici) high schools. As one may expect, the effect on grades is more pronounced for the former track, indicating that the scientific general education may provide more basic calculus skills than the humanistic one. We then find that graduates who took their high school degree in the North of Italy have a better performance than those who got their secondary education either in the Centre or in the South of Italy. Students from the North of Italy have 1 extra point compared with their peers coming from the South. This could be consistent with recent results about regional differences in the quality of maths training in high schools. Using Italian data from the 2003 wave of the OECD Programme for International Student Assessment (PISA), Checchi et al. (2007) find that the median difference between a Northern and a Southern region exceeds one standard deviation even if the organization of secondary education is strongly centralized. Checchi et al. (2007) argue that these differences may stem from different regional endowments in cultural and social capital. Hence our results seem to confirm that territorial variables are crucial in shaping student mathematical competencies at the secondary school level.

\footnotetext{
${ }^{12}$ It is worth noting that OLS methodology does not take into account that: i) we don't observe the grades for exams attempted but not passed; ii) grades higher than 31 are recorded as 31 . Our results, however, seem to be quite robust to the above mentioned problems, given that using a censored regression model we obtain fairly similar results to the OLS ones.
} 
Graduating from a state high school leads to a 0.5 extra point in maths. This could be an indication of the higher quality of education provided by state schools as it has been found by other empirical works applied to the Italian context (Cappellari, 2004; Bertola and Checchi, 2001). In order to analyze the impact on grades of having graduated from a certain high school track in a given school (state or private), we also report the estimated coefficients of equation (1) augmented with the interactions between high school degree and school type. These interactions, however, are never statistically significant.

The final high school grades is only weakly related to maths grades and males seem to perform worse than females. All the cohort dummies are significantly positive: students born before 1974, for example, have 1.6 extra points compared to younger students. This could give some evidence to the extended opinion that maths training at the secondary level has been deteriorating over time (Checchi et al., 2007).

The first year fee, which is a proxy for family income, seems to be unimportant for maths grades, and finally students who pass the exam in the first (second) year of the academic career have $1.2(0.4)$ higher grades than students who take the exam from the third year on, indicating that the former are better and more motivated students than the latter. Finally whether, maths exam is a prerequisite to pass other exams or not does not affect grades achievement.

Estimating equation (1) year by year or by high school type does not reveal any particular difference in associations between student characteristics and grades obtained over the years or according to the secondary school track (see Tables ?? and ?? in the Appendix).

The OLS estimates allow us to make statements about how factors shift the mean of maths grades distribution. To get a more complete picture of how various factors impact different quantiles of the conditional maths grades distribution, we use a quantile regression approach (Koenker and Bassett, 1978). 
Table ?? reports the quantile regressions estimates of equation (1). Quantile regressions are estimated at four different quantiles $(0.25 ; 0.50 ; 0.75 ; 0.90)$. To avoid the bandwidth choice required by the kernel estimator, we decide to use a bootstrap estimator for the standard errors. For each quantile estimator, 500 bootstrap replications are performed and the standard deviations are computed. For comparison, the results from the ordinary least squares regression are reported in the last column.

The ordinary least squares are quite similar to the 50\%-quantile (median) regression estimates, but the varying nature of the estimates at the other quantiles provides an interesting picture of how the distribution of maths grades is related to the covariates.

Note that the magnitude of the estimates for many of the variables (Humanities and Scientific high schools ${ }^{13}$, state high schools, cohort dummies) increases when moving from a lower quantile to a higher quantile; i.e. the marginal effects of the variables are larger at higher quantiles. Ordinary least squares overestimate the magnitude of these effects at the $10 \%$ quantile and underestimate the magnitude of these effects at the $90 \%$ quantile.

The Scientific and Other high schools differential in maths grades at the $10 \%$ quantile is 0.8 point. That is, holding all other things equal, the $10 \%$ quantile of maths grades for a student from a Scientific high school is 0.8 point higher the $10 \%$ quantile of maths grades for a student from an Other high school. The Scientific-Other high school differential increases to 1.5 at $75 \%$ quantiles. This is also true for cohort differential in maths grades (this is 0.7 at the $10 \%$ quantile and increases to 2.7 at the highest quantile), for the high school location variable (0.9 at the $10 \%$ quantile, 1.1 at $75 \%$ quantile) and for the dummy indicating whether the exam is taken in the first academic year (0.9 at the $10 \%$ quantile, 1.5 at $75 \%$ quantile).

The estimates for male dummy, on the other hand, decrease monotonically from the

\footnotetext{
${ }^{13}$ Contrary to the OLS estimates, we only report the effect of general high schools in case it is distinguished into "Scientific" (licei scientifici) and "Humanities" (licei classici) high schools
} 
lower quantiles to the higher quantiles (i.e. lower marginal effects at higher quantiles). The gender differential in maths grade seems to be more evident at lower quantiles of the maths grades distribution. The changing behavior of the coefficients along the distribution could be related to a latent individual characteristic, such as unobserved ability, implicitly indexed by each quantile of the maths grades distribution. If the latent characteristics were observable ex ante, then one could view the estimated coefficients of each quantile of maths grades distribution as an explicit interaction with this observable variable.

\subsection{The determinants of the elapsed time to pass maths exam}

The peculiarities of the Italian didactic organization mentioned above, lead us to investigate also the determinants of the time to take maths exam. Survival analysis is used to overcome the difficulties conventional statistical techniques have in modeling probability (Jenkins 2004). The duration variable of interest (time to take the exam) is measured in months and it is calculated as the difference between the date in which the student takes the exam and the first available date for taking the exam after the end of the maths course. ${ }^{14}$

The fact that the duration variable of interest is measured in months means that the appropriate approach to modeling the elapsed time to pass maths exam is the discrete-time hazard model. Following Meyer (1990), the discrete time hazard of passing the exam can be modeled using the discrete-time proportional hazards model. In particular, the hazard of passing the exam in the jth month, $h\left(t_{j}\right)$, for individual i with a vector of covariates, $\mathrm{x}$, given that the exam has not been taken before $\mathrm{t}_{j-1}$ can be given by:

\footnotetext{
${ }^{14}$ This has been identified conventionally with the month of June for the academic years 1993/1994 and 1995/1996 and with the month of January for the following academic years. The explanation is that initially the first available date for taking the exam was in June and after 1996 it was in January.
} 


$$
h_{i j}=1-\exp \left(-\exp \left(\gamma_{j}(t)+\left(z_{i} \beta\right)+u_{i}\right)\right), \text { where } \gamma_{j}(t)=\int_{-\infty}^{\infty} h_{o}(u) d u
$$

where $\gamma_{j}(t)$ represents the baseline hazard which has been specified flexibly ${ }^{15}, \mathrm{z}$ includes the vector of personal characteristics, X, all information on previous education A, the dummy variable related to whether the maths exam is a prerequisite to pass other exams and time fixed effects $T$. Unobserved heterogeneity is represented by $\mathrm{u}_{i}$ which is the $\log$ of a positive-valued random variable (mixture). The unobserved heterogeneity term is assumed to be independent of observed covariates, $\mathrm{z}_{i}$, and the random duration variable. Given that unobserved heterogeneity could be potentially correlated with both the elapsed time to take maths exam and the grades, we simultaneously model the probability of taking low, average, above average and high grades and the hazard of taking the exam. The probability of falling in each of the above grade categories depends on the same explanatory variables of the hazard model and an unobserved component is specified as an ordered probit model with discrete random effects. The categorized maths grades, $\mathrm{CG}_{i m}$, are determined from the model as follows:

$$
\begin{aligned}
& C G_{i m}^{*}=z_{i}^{\prime} \pi+\varepsilon_{i}+v_{i} \\
& C G_{i m}=\text { low grades if } y_{i}^{*}<0 \\
& C G_{i m}=\text { average grades if } 0 \leqq y_{i}^{*}<\zeta_{1} \\
& C G_{i m}=\text { above average grades if } \zeta_{1} \leqq y_{i}^{*}<\zeta_{2} \\
& C G_{i m}=\text { high grades if } y_{i}^{*} \geqq \zeta_{2}
\end{aligned}
$$

\footnotetext{
${ }^{15}$ The baseline hazard function has a piecewise constant specification, such that it is constant within duration intervals.
} 
where $\varepsilon_{i}$ is unobserved heterogeneity and $v_{i}$ is an error term, assumed to follow a standard normal distribution. We assume that all sources of correlation between the two processes beyond those captured by the observed explanatory variables can be represented by the individual-specific heterogeneity terms. Assuming that we observe a student i's spell from month $\mathrm{k}=1$ through the end of the $\mathrm{jth}$ month, at which point i's spell is either complete $\left(c_{i}=1\right)$ or right-censored $\left(c_{i}=0\right)$, and defining a new binary indicator variable $\mathrm{y}_{i k}=1$ if student $\mathrm{i}$ passes the maths exam in month $\mathrm{k}$, and $\mathrm{y}_{i k}=0$ otherwise, the individual contribution to the likelihood function in our model is:

$\log L=\int_{-\infty}^{+\infty}\left(\prod_{j}^{t} h_{j}\left(t, z_{i} \mid u_{i}\right)^{y_{i j}}\left(1-h_{j}\left(t, z_{i} \mid u_{i}\right)^{1-y_{i j}}\right) \prod_{C G_{i m}=s}\left(\Phi\left(\zeta_{s}-z_{i}^{\prime} \mid \varepsilon_{i}\right)-\Phi\left(\zeta_{s-1}-z_{i}^{\prime} \mid \varepsilon_{i}\right)\right)\right) d G(u, \varepsilon)$

$G(u, \varepsilon)$ is the joint cdf of the unobservables. We use a flexible and widely applied specification of the distribution of the unobservables; it is assumed that $u$ and $\varepsilon$ can take two values. Thus, there are two possible combinations of this bivariate unobserved heterogeneity distribution, each with an associated probability. For more details on this class of mixture distributions in duration models, see, e.g., Van den Berg (2001).

A first impression of the association between the grades and the time to pass the exam is obtained by plotting different Lifetable estimates of the hazard of passing the exam. In Figure 1, we show the non-parametric single risk hazard functions for taking the maths exam. We distinguish between the grades categories presented above. As can be seen, over the first months students with high grades have a consistently higher hazard rate than students with average or low grades. The other way around if we consider very long durations, i.e. the longer students wait to take the exam, the less likely they are to obtain high grades. Moreover, the null hypothesis of equality of 
survivor functions for different groups is rejected by both the log-rank and Wilcoxon tests (see Table ??).

The results of the simultaneous model described above are given in Table ??. The first column shows estimated coefficients and their standard errors of the hazard of passing maths exam, while the second one contains paramater estimates and standard errors of the maths grades equation. With respect to explanatory variables of maths grades, it appears that women and students with higher high school grades are more likely to get higher grades in maths exam, as the OLS and quintile regressions suggest. Also, graduates from Scientific or Humanities high schools are more likely to achieve higher grades, as the students graduated from a state high school or coming from the North of Italy. Younger students are more likely to perform bad compared to their older counterparts. Finally, contrary to the previous models, when the maths exam is a prerequisite to pass other exams, the students are more likely to achieve lower grades. From the first column of Table ??, we can see that the probability of passing maths exam is increasing with final high school grades and scientific secondary education and is negatively correlated with technical education. With regard to gender differences, female students have a $6 \%$ higher hazard of passing maths exam compared with their male counterparts. The results also indicate that state versus private high schools slightly improves the speed at which the students pass maths exam: graduating from a state high school significantly increases the hazard rate of taking the exam. The probability of taking maths exam is also significantly correlated with high school location: graduates from a high school located in the North of Italy have a higher hazard of taking maths exam than graduates from the Centre or South of Italy. This result confirms again the territorial differences in Italian students' mathematical competencies. Another interesting result is that younger students (born after 1980) have a higher hazard of taking maths exam than their older counterparts. Finally, when the maths exam is a prerequisite to pass other exams, the students seem to be faster to 
take it. The unobserved heterogeneity terms in the grades equation and in the hazard rate are clearly correlated, so it is of importance to estimate them simultaneously. The estimated correlation is positive indicating that the longer students wait to take the exam, the less likely they are to obtain high grades. This result may suggest that the students taking longer to pass maths exam are not only those who need to put more effort to catch up the most brilliant students but are also those who repeat the exam several times until they pass the minimum required maths ability threshold.

All these results confirm that there is great heterogeneity of ability among Italian university students, given that no selection procedure exists at the enrollment. The most able students pass the exam immediately and with good grades while their peers with fewer numeracy skills need to put more effort and to study longer in order to pass the minimum required maths ability threshold, given that their learning process is longer. But we show that among students who take longer to take maths exam some put a very low effort and repeat the exam several times until they get the minimum required maths ability threshold to pass the exam. As we mentioned in the previous sections, only $60 \%$ of the sampled students pass the exam in the first academic year. Hence about one half of the students take longer to pass the exam and are more likely to perform worse than those students who pass the exam immediately. One important policy implication of these results is that the actual didactic organization of Italian universities ${ }^{16}$ implies considerable costs for students in terms of wasted time associated with the unsatisfactory experiences of failure and repetition of the exam without limitations, the latter prolonging the time to graduation with lower chances to perform well. If a different system was adopted where the exam could not be repeated without limitations and a strong selection procedure at the enrollment (like in most other European countries), this would permit any enrollment target that limits

\footnotetext{
${ }^{16}$ The didactic organization of Italian universities remained largely untouched by the recent university reforms.
} 
enrollment below the unconstrained demand to be met, but in such a way that the loss of students most likely to succeed is minimized as well as the gain of students who would take longer to graduate and who are more likely to have a low performance. This would allow the latter to select into more appropriate fields of study where they could have better chance of success.

\section{Conclusions}

This paper is concerned with the factors that determine individual success in the first year mathematics exam for students in Economics. The aim of this study is twofold. On the one hand, we will shed some light on the main factors associated with maths grades fitting an educational production function. On the other hand, we analyze the determinants of the elapsed time to pass the exam through a survival analysis. Given that data requirements for the empirical analysis are very demanding, we analyze students' performance in maths using a very detailed and large sample covering 10 years, drawn from the administrative database of Cattolica University.

The overall results of the empirical analysis indicate that final high school grades and higher pre-college maths knowledge are positively correlated. Females typically do better than males, controlling for all other factors, and family income influences the academic performance negatively. Consistent with other studies (Checchi et al., 2007), we find some evidence of territorial differences in Italian students' mathematical competencies. Finally, duration analysis on the elapsed time to take maths exam indicate that the longer students wait to take the exam, the less likely they are to obtain high grades. This confirms that there is great heterogeneity of ability among Italian university students, given that no selection procedure exists at the enrollment. The most able students pass the exam immediately and with good grades while their 
peers with fewer numeracy skills need to put more effort and to study longer in order to pass the minimum required maths ability threshold, given that their learning process is longer. But we also show that among students who take longer to take maths exam some put a very low effort and repeat the exam several times until they get the minimum required maths ability threshold to pass the exam.

One important policy implication of these results is that if a different system was adopted where the exam could not be repeated without limitations and a strong selection procedure at the enrollment (like in most other European countries), this would permit any enrollment target that limits enrollment below the unconstrained demand to be met, but in such a way that the loss of students most likely to succeed is minimized, as well as the gain of students who would take longer to graduate and who are more likely to have a very low performance. 


\section{References}

[1] Anderson G.; Benjamin D. and Fuss M. (1994) "The Determinants of Success in University Introductory Economics Courses"; The Journal of Economic Education, Vol.25, No.2, pp.99-119.

[2] Bishop, John H. (1989) "Is the Test Score Decline Responsible for the Productivity Growth Decline?" American Economic Review 79(1): 178-97.

[3] Bertola, G. and Checchi D. (2001) "Sorting and Private Education in Italy", Lavoro e Relazioni Industriali 2/2001: 87-124.

[4] Bratti M.; Broccolini C. and Staffolani S. (2006) "Is 3+2 Equal to 4? University Reform and Student Academic Performance in Italy"; mimeo.

[5] Bratti M.; Staffolani S. (2002) "Student Time Allocation and Educational Production Functions"; mimeo.

[6] Cappellari L. (2004) "High school types, academic performance and early labor gradeset outcomes"; IZA working paper.

[7] Case A., Deaton A. (1999) "School Inputs and Educational Outcomes in South Africa", Quarterly Journal of Economics, 114, 1047-1084.

[8] Charette M., Meng R. (1998) "The Determinants of Literacy and Numeracy, and the Effect of Literacy and Numeracy on Labour gradeset Outcomes", The Canadian Journal of Economics / Revue canadienne d'Economique, Vol. 31, No. 3 (Aug., 1998), pp. 495-517.

[9] Checchi D.; Franzoni F.; Ichino A. and Rustichini A. (2000) "College choice and academic performance"; mimeo. 
[10] Checchi D., Bratti M. and Filippin A. (2007) "Territorial differences in Italian students' mathematical competences: evidence from PISA", IZA Discussion Paper No.2603/2007.

[11] Cohn E., Cohn S., Hult R., Balch D. and Bradley J. (1999), "The Effects of Mathematics Background on Student Learning in Principles of Economics", Journal of Education for Business, September/October.

[12] Desjardins, R. (2004), "Learning for Well Being: Studies Using the International Adult Literacy Survey", Institute of International Education, Stockholm University, Stokholm.

[13] Dolado J. and Morales E. (2006) "What Makes an Udergraduate Student in Economics Good in Maths? Some Spanish Evidence", mimeo.

[14] Durden, G. C. and Ellis, L.V. (1995) "The Effects of Attendance on Student Learning in Principles of Economics"; American Economic Review, 85(2), 343346.

[15] Hanushek, E. (1995) "Interpreting Recent Research on Schooling in Developing Countries", World Bank Research Observer, 10, 227-246.

[16] Jenkins, S.P. (2004) "Survival Analysis", mimeo, Department of Economics, University of Essex, UK.

[17] Ma X. (2001) "A national assessment of mathematics participation in the United States: A survival analysis model for describing students' academic careers". Lewiston, NY: Edwin Mellen.

[18] McIntosh, S. and Vignoles, A., 2001. "Measuring and Assessing the Impact of Basic Skills on Labour gradeset Outcomes," Oxford Economic Papers, Oxford University Press, vol. 53(3), pages 453-81, July. 
[19] McNabb R., Sarmistha P. and Sloane P. (2002), "Gender Differences in Sudent Attainment: the Case of University Students in the UK", Economica, vol.69, pp.481-503.

[20] Meyer B. D. (1990), "Unemployment Insurance and Unemployment Spells " Econometrica 58: 757-782.

[21] Murnane, R. J. (1988) "Education and the Productivity of the Work Force: Looking Ahead". In American Living Standards: Threats and Challanges, ed. M.N. Baily, M. Blair, R.W. Crandall, F. Levy. Washington, D.C.: The Brookings Institution.

[22] King H. (1999) "The Determinants of Success in First-Year Economics Courses: an Educational Production Function Approach", mimeo.

[23] Kirsch, I. S., Jungeblut, A., Jenkins, L. and Kolstad, A. (1993), ” Adult Literacy in America: A First Look at the Results of the National Adult Literacy Survey, Educational Testing Service", Princeton, NJ.

[24] Koenker, R. and Bassett G. (1978) "Regression Quantiles", Econometrica, 46, $33-50$.

[25] OECD and Statistics Canada (2000), Literacy in the Information Age: Final Report on the International Adult Literacy Survey, Paris and Ottawa.

[26] OECD (2005). Adult illiteracy and economic performance. Paris: Centre for Educational Research and Innovation, OECD.

[27] Rivera-Batiz, F. (1992) "Quantitative literacy and the likelihood of employment among young adults in the United States" Journal of Human Resources, vol.27, no.2. Spring p.313-328. 
[28] Sabot R. and Linn J. (1991) "Determinants of Performance in Introductory Courses in Economics and Seven Other Disciplines", mimeo.

[29] Smith J. and Naylor R. (2001) "Determinants of individual degree performance performance: evidence for the 1983 UK university graduate population from the USR", Oxford Bulletin of Economics and Statistics, vol.63, pp.29-60.

[30] Tuijnman, A.C. and Boudard, E. (2000) "Adult Education Participation in North America: International Perspectives", United States Department of Education, Office for Vocational and Adult Education, Washington, D.C.

[31] Van den Berg G. (2001), "Duration Models: Specification, Identification and Multiple Durations", in Handbook of Econometrics, edited by Heckman, James J. and Leamer Edward, V, North-Holland, Amsterdam. 
Table 1: Summary Statistics.

\begin{tabular}{|c|c|c|c|c|c|}
\hline Variables & $\mathrm{N}$ & Mean & Std. & Min & Max \\
\hline Maths grades & 10793 & 22.41 & 3.61 & 18 & 31 \\
\hline \multicolumn{6}{|l|}{ Exam year } \\
\hline 1993 & 10812 & 0.03 & 0.16 & 0 & 1 \\
\hline 1994 & 10812 & 0.07 & 0.25 & 0 & 1 \\
\hline 1995 & 10812 & 0.09 & 0.28 & 0 & 1 \\
\hline 1996 & 10812 & 0.05 & 0.22 & 0 & 1 \\
\hline 1997 & 10812 & 0.09 & 0.28 & 0 & 1 \\
\hline 1998 & 10812 & 0.08 & 0.26 & 0 & 1 \\
\hline 1999 & 10812 & 0.08 & 0.27 & 0 & 1 \\
\hline 2000 & 10812 & 0.07 & 0.25 & 0 & 1 \\
\hline 2001 & 10812 & 0.07 & 0.25 & 0 & 1 \\
\hline 2002 & 10812 & 0.10 & 0.30 & 0 & 1 \\
\hline 2003 & 10812 & 0.07 & 0.26 & 0 & 1 \\
\hline 2004 & 10812 & 0.07 & 0.25 & 0 & 1 \\
\hline 2005 & 10812 & 0.07 & 0.26 & 0 & 1 \\
\hline 2006 & 10812 & 0.05 & 0.22 & 0 & 1 \\
\hline Exam taken in the first year & 10812 & 0.59 & 0.49 & 0 & 1 \\
\hline Exam taken in the second year & 10812 & 0.24 & 0.42 & 0 & 1 \\
\hline Exam taken in the third year & 10812 & 0.17 & 0.37 & 0 & 1 \\
\hline \multicolumn{6}{|l|}{ Personal characteristics } \\
\hline Gender (males) & 10812 & 0.56 & 0.49 & 0 & 1 \\
\hline Final high school grades & 10758 & 78.29 & 11.66 & 60 & 100 \\
\hline First year fee & 10812 & 28.89 & 12.54 & 0 & 249.61 \\
\hline General high school & 10812 & 0.58 & 0.49 & 0 & 1 \\
\hline Professional/Vocational high school & 10812 & 0.37 & 0.48 & 0 & 1 \\
\hline Other high school & 10812 & 0.05 & 0.22 & 0 & 1 \\
\hline Public high school & 10812 & 0.75 & 0.43 & 0 & 1 \\
\hline Cohort 1 & 10812 & 0.21 & 0.40 & 0 & 1 \\
\hline Cohort 2 & 10812 & 0.35 & 0.47 & 0 & 1 \\
\hline Cohort 3 & 10812 & 0.44 & 0.49 & 0 & 1 \\
\hline Location school (South or Centre) & 10812 & 0.08 & 0.26 & 0 & 1 \\
\hline Location school (North) & 10812 & 0.92 & 0.27 & 0 & 1 \\
\hline Maths exam prerequisite & 10812 & 0.26 & 0.43 & 0 & 1 \\
\hline
\end{tabular}


Table 2: Percentage of students who passed the maths exam in first year.

\begin{tabular}{lccc}
\hline Academic year & Enrolled students & $\begin{array}{c}\text { Percentage passing the maths } \\
\text { exam in the first year }\end{array}$ & $\begin{array}{c}\text { Mean of final high school } \\
\text { grades of enrolled students }\end{array}$ \\
\hline $1992 / 93$ & 1,220 & 0.29 & 78.29 \\
$1993 / 94$ & 1,170 & 0.31 & 81.44 \\
$1994 / 95$ & 1,116 & 0.43 & 79.62 \\
$1995 / 96$ & 1,091 & 0.32 & 78.07 \\
$1996 / 97$ & 1,127 & 0.47 & 77.4 \\
$1997 / 98$ & 874 & 0.52 & 76.88 \\
$1998 / 99$ & 703 & 0.69 & 76.31 \\
$1999 / 2000$ & 724 & 0.78 & 78.51 \\
$2000 / 2001$ & 1,096 & 0.69 & 75.43 \\
$2001 / 2002$ & 1,374 & 0.81 & 76.79 \\
$2002 / 2003$ & 1,195 & 0.71 & 80.47 \\
$2003 / 2004$ & 1,076 & 0.76 & 81.17 \\
$2004 / 2005$ & 1,151 & 0.90 & 81.06 \\
$2005 / 2006$ & 1,160 & 0.90 & 80.07 \\
\hline \hline
\end{tabular}

Table 3: Distribution of maths grades by gender.

\begin{tabular}{lccccc}
\hline \multicolumn{7}{c}{ maths grades } \\
\hline gender & $\mathbf{1 8 - 2 0}$ & $\mathbf{2 1 - 2 4}$ & $\mathbf{2 5 - 2 7}$ & $\mathbf{2 8 - 3 1}$ & Total \\
\hline female & 35.72 & 34.42 & 18.76 & 11.10 & 43.66 \\
male & 40.27 & 33.65 & 17.40 & 8.68 & 56.34 \\
\hline Total & 38.28 & 33.98 & 17.99 & 9.74 & 100.00 \\
\hline
\end{tabular}

Table 4: Distribution of maths grades by final high school grades.

\begin{tabular}{lccccc}
\hline & \multicolumn{5}{c}{ maths grades } \\
\hline high school final grades & $\mathbf{1 8 - 2 0}$ & $\mathbf{2 1 - 2 4}$ & $\mathbf{2 5 - 2 7}$ & $\mathbf{2 8 - 3 1}$ & Total \\
\hline $60-70$ & 47.28 & 33.13 & 14.47 & 5.12 & 30.93 \\
$71-80$ & 40.11 & 34.85 & 17.93 & 7.10 & 30.79 \\
$81-90$ & 33.51 & 35.23 & 20.32 & 10.95 & 20.66 \\
$91-100$ & 24.89 & 32.40 & 21.83 & 20.88 & 17.61 \\
\hline Total & 38.29 & 33.97 & 18.04 & 9.71 & 100.00 \\
\hline
\end{tabular}

Table 5: Distribution of maths grades by high school type.

\begin{tabular}{lccccc}
\hline \multicolumn{5}{c}{ maths grades } \\
\hline high school & $\mathbf{1 8 - 2 0}$ & $\mathbf{2 1 - 2 4}$ & $\mathbf{2 5 - 2 7}$ & $\mathbf{2 8 - 3 1}$ & Total \\
\hline General & 34.80 & 34.00 & 19.78 & 11.42 & 57.91 \\
Professional/Vocational & 42.76 & 33.93 & 16.01 & 7.30 & 36.92 \\
Other & 45.34 & 34.23 & 12.19 & 8.24 & 5.17 \\
\hline Total & 38.28 & 33.98 & 17.99 & 9.74 & 100.00 \\
\hline
\end{tabular}


Table 6: Distribution of maths grades by secondary school institution type.

\begin{tabular}{lccccc}
\hline \multicolumn{5}{c}{ maths grades } \\
\hline institution type & $\mathbf{1 8 - 2 0}$ & $\mathbf{2 1 - 2 4}$ & $\mathbf{2 5 - 2 7}$ & $\mathbf{2 8 - 3 1}$ & Total \\
\hline private & 44.64 & 32.12 & 16.06 & 7.18 & 25.16 \\
public & 36.15 & 34.61 & 18.64 & 10.60 & 74.84 \\
\hline Total & 38.28 & 33.98 & 17.99 & 9.74 & 100.00 \\
\hline
\end{tabular}

Table 7: Log-rank and Wilcoxon (Breslow) tests.

\begin{tabular}{lccc}
\hline Log-rank test for equality of survivor functions & $\begin{array}{c}\text { Events } \\
\text { observed }\end{array}$ & $\begin{array}{c}\text { Events } \\
\text { expected }\end{array}$ & \\
Low grades & 5020 & 5887.56 & \\
Average grades & 4464 & 4288.54 & \\
Above average grades & 2337 & 2045.51 & \\
High grades & 1199 & 798.4 & \\
Total & 13020 & 13020 & \\
& chi2 $2(4)=$ & 444.92 & \\
& Pr $\geq$ chi2 $=$ & 0 & \\
\hline Wilcoxon (Breslow) test & Events & Events & Sum of \\
& observed & expected & ranks \\
& & & \\
Low grades & 5020 & 5887.56 & -7916472 \\
Average grades & 4464 & 4288.54 & 1042448 \\
Above average grades & 2337 & 2045.51 & 2567327 \\
High grades & 1199 & 798.4 & 4306697 \\
Total & & & \\
& chi2 $(4)=$ & 604.62 & \\
\hline
\end{tabular}


Table 8: Ols estimates; dependent variables: Maths grades.

\begin{tabular}{|c|c|c|}
\hline & Model1 & Model2 \\
\hline Gender(males) & $\begin{array}{c}-0.170^{* *} \\
(0.069)\end{array}$ & $\begin{array}{c}-0.195^{* * *} \\
(0.069)\end{array}$ \\
\hline Final high school grades & $\begin{array}{c}0.080 * * * \\
(0.003)\end{array}$ & $\begin{array}{c}0.081^{* * *} \\
(0.003)\end{array}$ \\
\hline First year fee & $\begin{array}{l}-0.001 \\
(0.003)\end{array}$ & $\begin{array}{l}-0.001 \\
(0.003)\end{array}$ \\
\hline General high school & $\begin{array}{c}1.029^{* * *} * \\
(0.224)\end{array}$ & \\
\hline Humanities high school & & $\begin{array}{c}0.751^{* * *} \\
(0.289)\end{array}$ \\
\hline Scientific high school & & $\begin{array}{c}1.113^{* * *} \\
(0.227)\end{array}$ \\
\hline Professional/Vocational high school & $\begin{array}{c}0.069 \\
(0.237)\end{array}$ & $\begin{array}{c}0.071 \\
(0.237)\end{array}$ \\
\hline Public high school & $\begin{array}{l}0.570^{*} \\
(0.306)\end{array}$ & $\begin{array}{l}0.574^{*} \\
(0.306)\end{array}$ \\
\hline Public school*General & $\begin{array}{c}0.139 \\
(0.321)\end{array}$ & \\
\hline Public school*Scientific & & $\begin{array}{c}0.154 \\
(0.323)\end{array}$ \\
\hline Public school*Humanities & & $\begin{array}{l}-0.065 \\
(0.387)\end{array}$ \\
\hline Public school* Professional/Vocational & $\begin{array}{l}-0.272 \\
(0.332)\end{array}$ & $\begin{array}{l}-0.279 \\
(0.332)\end{array}$ \\
\hline Cohort1 & $\begin{array}{c}1.583^{* * *} \\
(0.205)\end{array}$ & $\begin{array}{c}1.584^{* * *} \\
(0.205)\end{array}$ \\
\hline Cohort2 & $\begin{array}{c}1.046^{* * *} \\
(0.156)\end{array}$ & $\begin{array}{c}1.041^{* * *} \\
(0.157)\end{array}$ \\
\hline Location school (north) & $\begin{array}{c}1.005^{* * *} \\
(0.126)\end{array}$ & $\begin{array}{c}0.948^{* * *} \\
(0.127)\end{array}$ \\
\hline Exam passed in the first year & $\begin{array}{c}1.196^{* * *} \\
(0.115)\end{array}$ & $\begin{array}{c}1.152^{* * *} \\
(0.116)\end{array}$ \\
\hline Exam passed in the second year & $\begin{array}{c}0.420^{* * *} \\
(0.113)\end{array}$ & $\begin{array}{c}0.414^{* * *} \\
(0.113)\end{array}$ \\
\hline Maths exam prerequisite & $\begin{array}{l}-0.085 \\
(0.168)\end{array}$ & $\begin{array}{r}-0.084 \\
(0.168)\end{array}$ \\
\hline $\begin{array}{l}\text { R sq. } \\
N\end{array}$ & $\begin{array}{l}0.131 \\
10743\end{array}$ & $\begin{array}{c}0.132 \\
10743\end{array}$ \\
\hline
\end{tabular}

Notes: Robust standard errors in parentheses; ${ }^{* * *}$ Significant at the $1 \%$ level **Significant at the $5 \%$ level *Significant at the $10 \%$ level. All regressions include time dummies. 


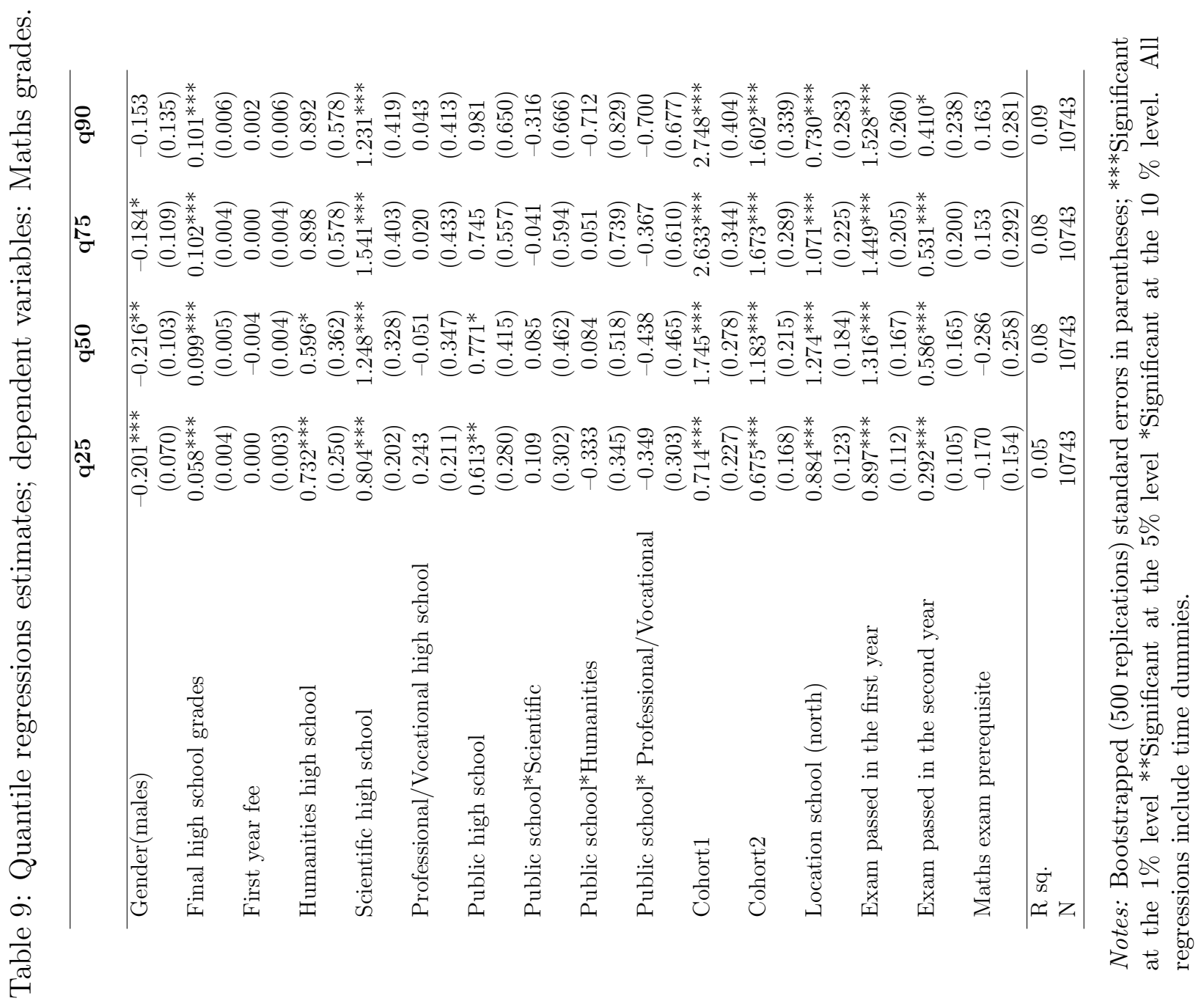




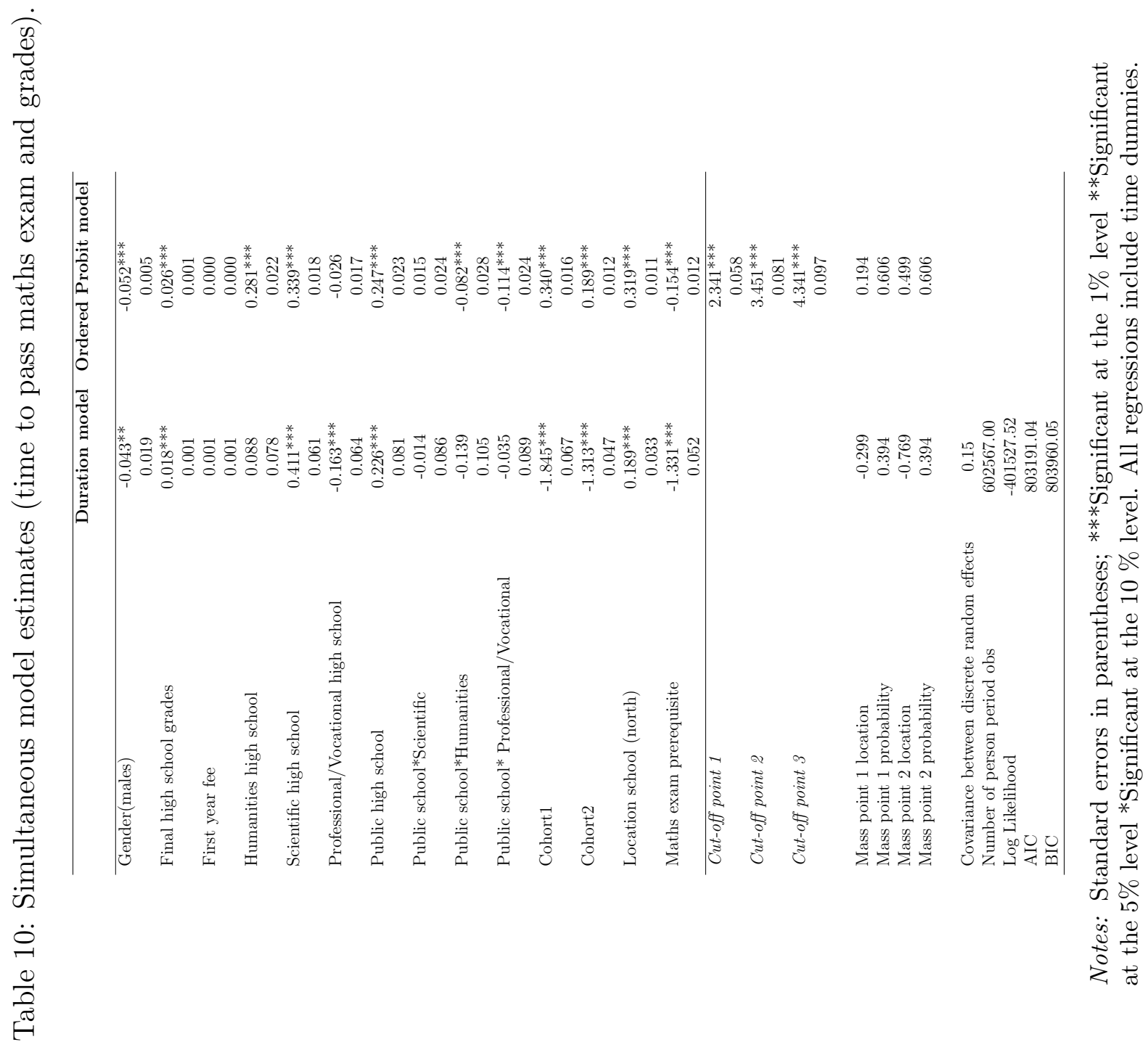


Appendix: Additional Results.

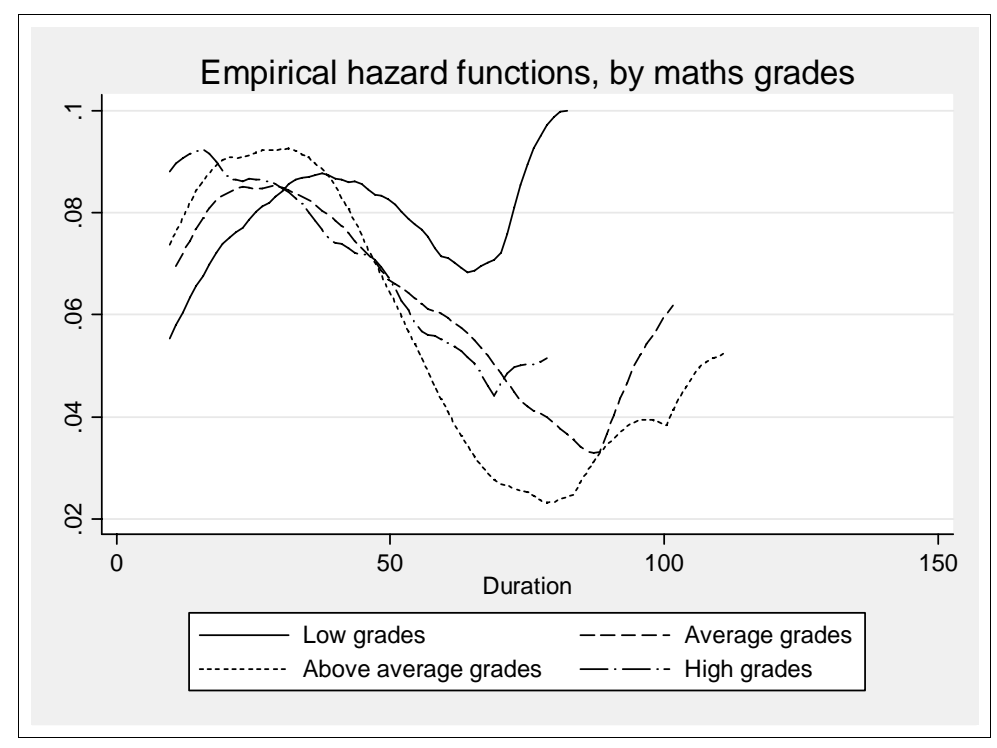

Figure 1: Empirical Hazard Function. 


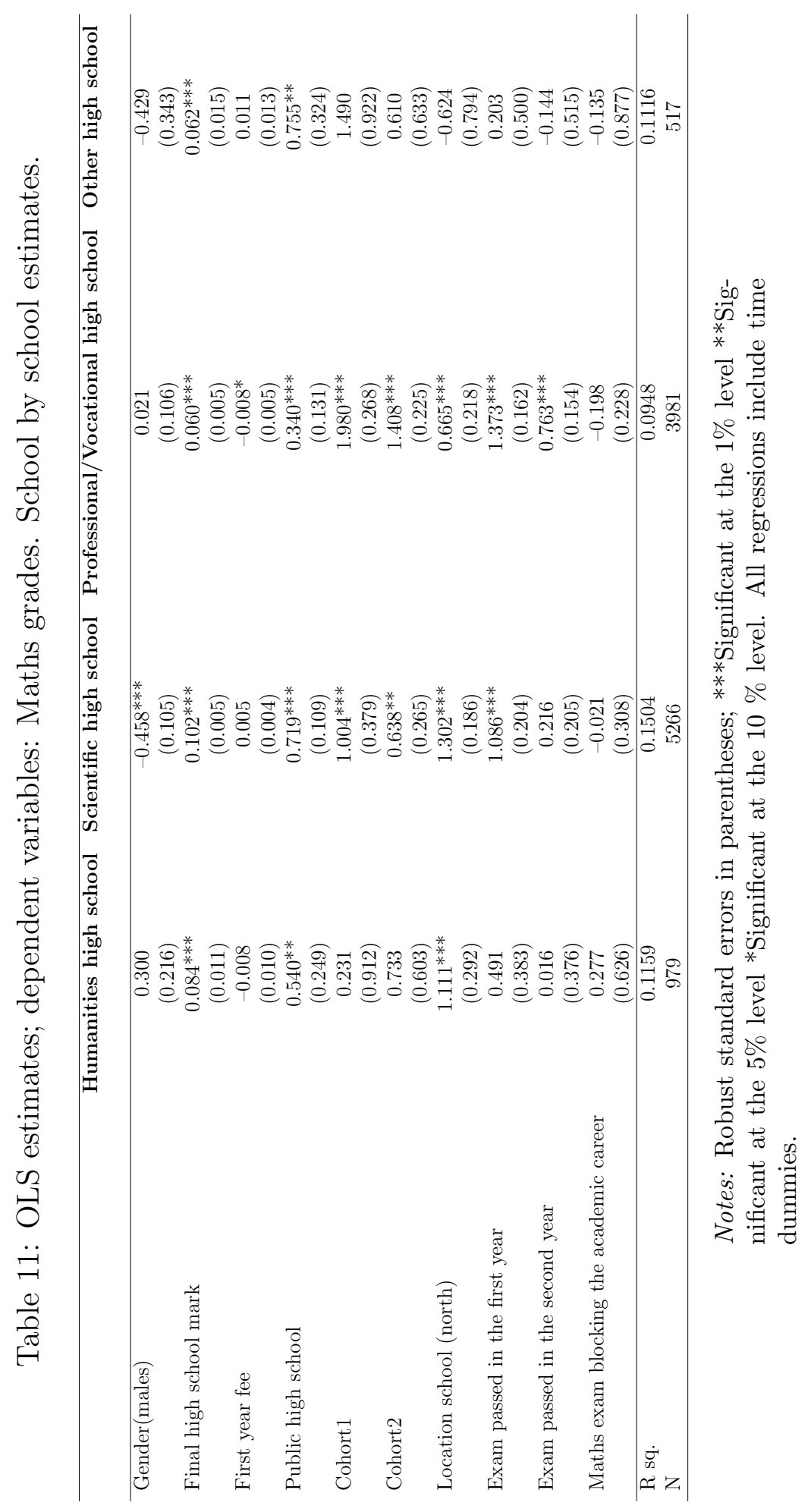




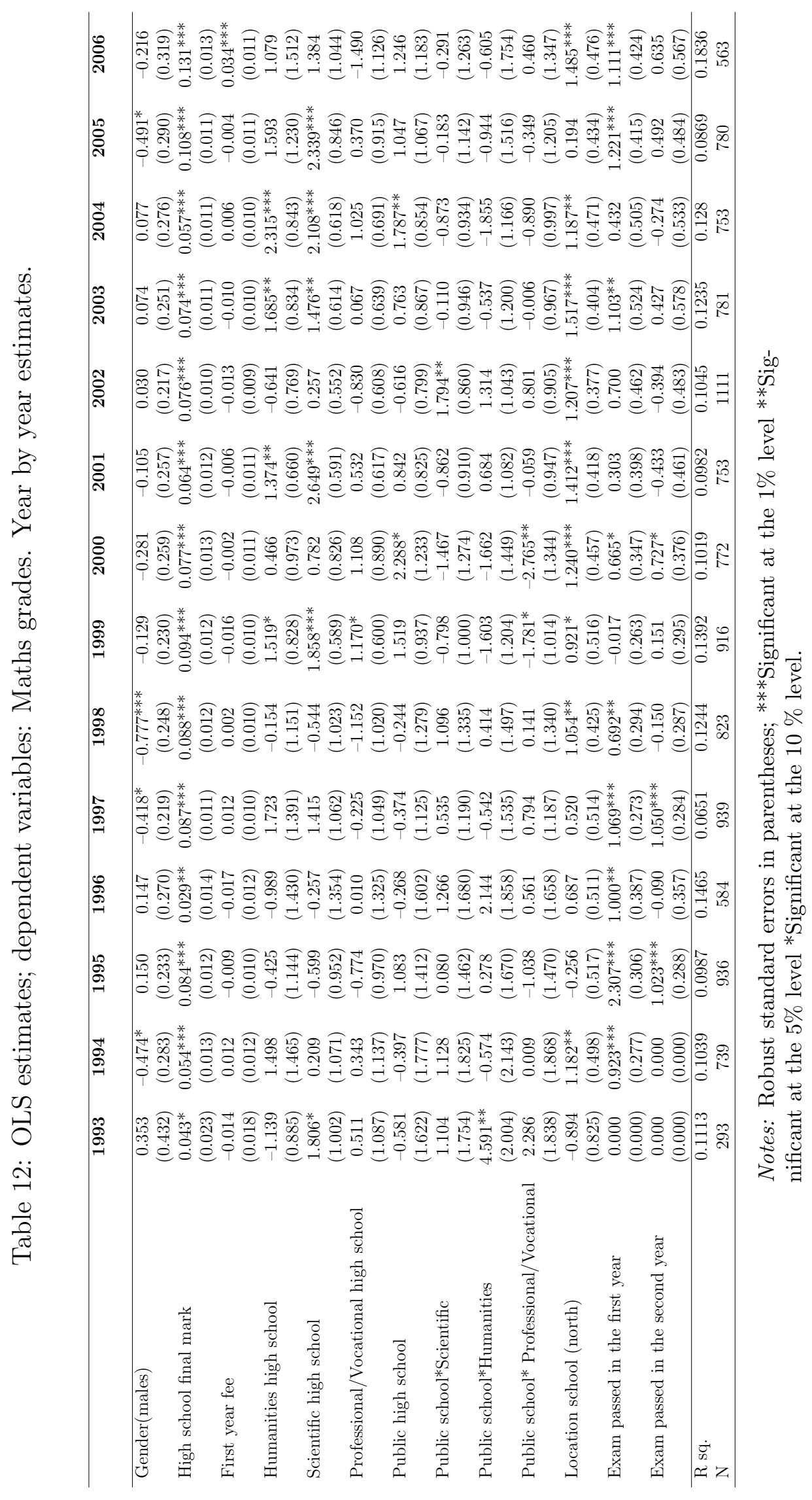


Department of Economics:

Skriftserie/Working Paper:

2003:

WP 03-1 Søren Harck: Er der nu en strukturelt bestemt langsigts-ledighed i SMEC?: Phillipskurven i SMEC 99 vis-à-vis SMEC 94. ISSN 1397-4831.

WP 03-2 Beatrice Schindler Rangvid: Evaluating Private School Quality in Denmark. ISSN 1397-4831.

WP 03-3 Tor Eriksson: Managerial Pay and Executive Turnover in the Czech and Slovak Republics. ISSN 1397-4831.

WP 03-4 Michael Svarer and Mette Verner: Do Children Stabilize Marriages? ISSN 1397-4831.

WP 03-5 Christian Bjørnskov and Gert Tinggaard Svendsen: Measuring social capital - Is there a single underlying explanation? ISSN 1397-4831.

WP 03-6 Vibeke Jakobsen and Nina Smith: The educational attainment of the children of the Danish 'guest worker' immigrants. ISSN 1397-4831.

WP 03-7 Anders Poulsen: The Survival and Welfare Implications of Altruism When Preferences are Endogenous. ISSN 1397-4831.

WP 03-8 Helena Skyt Nielsen and Mette Verner: Why are Well-educated Women not Full-timers? ISSN 1397-4831.

WP 03-9 Anders Poulsen: On Efficiency, Tie-Breaking Rules and Role Assignment Procedures in Evolutionary Bargaining. ISSN 13974831.

WP 03-10 Anders Poulsen and Gert Tinggaard Svendsen: Rise and Decline of Social Capital

- Excess Co-operation in the One-Shot Prisoner's Dilemma Game. ISSN 1397-4831. 
WP 03-11 Nabanita Datta Gupta and Amaresh Dubey: Poverty and Fertility: An Instrumental Variables Analysis on Indian Micro Data. ISSN 1397-4831.

WP 03-12 Tor Eriksson: The Managerial Power Impact on Compensation Some Further Evidence. ISSN 1397-4831.

WP 03-13 Christian Bjørnskov: Corruption and Social Capital. ISSN 13974831.

WP 03-14 Debashish Bhattacherjee: The Effects of Group Incentives in an Indian Firm

- Evidence from Payroll Data. ISSN 1397-4831.

WP 03-15 Tor Eriksson och Peter Jensen: Tidsbegränsade anställninger danska erfarenheter. ISSN 1397-4831.

WP 03-16 Tom Coupé, Valérie Smeets and Frédéric Warzynski: Incentives, Sorting and Productivity along the Career: Evidence from a Sample of Top Economists. ISSN 1397-4831.

WP 03-17 Jozef Koning, Patrick Van Cayseele and Frédéric Warzynski: The Effects of Privatization and Competitive Pressure on Firms' Price-Cost Margins: Micro Evidence from Emerging Economies. ISSN 1397-4831.

WP 03-18 Urs Steiner Brandt and Gert Tinggaard Svendsen: The coalition of industrialists and environmentalists in the climate change issue. ISSN 1397-4831.

WP 03-19 Jan Bentzen: An empirical analysis of gasoline price convergence for 20 OECD countries. ISSN 1397-4831.

WP 03-20 Jan Bentzen and Valdemar Smith: Regional income convergence in the Scandinavian countries. ISSN 1397-4831.

WP 03-21 Gert Tinggaard Svendsen: Social Capital, Corruption and Economic Growth: Eastern and Western Europe. ISSN 13974831.

WP 03-22 Jan Bentzen and Valdemar Smith: A Comparative Study of Wine Auction Prices: Mouton Rothschild Premier Cru Classé. ISSN 1397-4831. 
WP 03-23 Peter Guldager: Folkepensionisternes incitamenter til at arbejde. ISSN 1397-4831.

WP 03-24 Valérie Smeets and Frédéric Warzynski: Job Creation, Job Destruction and Voting Behavior in Poland. ISSN 1397-4831.

WP 03-25 Tom Coupé, Valérie Smeets and Frédéric Warzynski: Incentives in Economic Departments: Testing Tournaments? ISSN 13974831.

WP 03-26 Erik Strøjer Madsen, Valdemar Smith and Mogens DillingHansen: Industrial clusters, firm location and productivity Some empirical evidence for Danish firms. ISSN 1397-4831.

WP 03-27 Aycan Çelikaksoy, Helena Skyt Nielsen and Mette Verner: Marriage Migration: Just another case of positive assortative matching? ISSN 1397-4831.

2004:

WP 04-1 Elina Pylkkänen and Nina Smith: Career Interruptions due to Parental Leave - A Comparative Study of Denmark and Sweden. ISSN 1397-4831.

WP 04-2 Urs Steiner Brandt and Gert Tinggaard Svendsen: Switch Point and First-Mover Advantage: The Case of the Wind Turbine Industry. ISSN 1397-4831.

WP 04-3 Tor Eriksson and Jaime Ortega: The Adoption of Job Rotation: Testing the Theories. ISSN 1397-4831.

WP 04-4 Valérie Smeets: Are There Fast Tracks in Economic Departments? Evidence from a Sample of Top Economists. ISSN 1397-4831.

WP 04-5 Karsten Bjerring Olsen, Rikke Ibsen and Niels WestergaardNielsen: Does Outsourcing Create Unemployment? The Case of the Danish Textile and Clothing Industry. ISSN 1397-4831.

WP 04-6 Tor Eriksson and Johan Moritz Kuhn: Firm Spin-offs in Denmark 1981-2000 - Patterns of Entry and Exit. ISSN 13974831. 
WP 04-7 Mona Larsen and Nabanita Datta Gupta: The Impact of Health on Individual Retirement Plans: a Panel Analysis comparing Self-reported versus Diagnostic Measures. ISSN 1397-4831.

WP 04-8 Christian Bjørnskov: Inequality, Tolerance, and Growth. ISSN 1397-4831.

WP 04-9 Christian Bjørnskov: Legal Quality, Inequality, and Tolerance. ISSN 1397-4831.

WP 04-10 Karsten Bjerring Olsen: Economic Cooperation and Social Identity: Towards a Model of Economic Cross-Cultural Integration. ISSN 1397-4831.

WP 04-11 Iben Bolvig: Within- and between-firm mobility in the low-wage labour market. ISSN 1397-4831.

WP 04-12 Odile Poulsen and Gert Tinggaard Svendsen: Social Capital and Market Centralisation: A Two-Sector Model. ISSN 1397-4831.

WP 04-13 Aditya Goenka and Odile Poulsen: Factor Intensity Reversal and Ergodic Chaos. ISSN 1397-4831.

WP 04-14 Jan Bentzen and Valdemar Smith: Short-run and long-run relationships in the consumption of alcohol in the Scandinavian countries.

ISBN 87-7882-010-3 (print); ISBN 87-7882-011-1 (online).

WP 04-15 Jan Bentzen, Erik Strøjer Madsen, Valdemar Smith and Mogens Dilling-Hansen: Persistence in Corporate Performance? Empirical Evidence from Panel Unit Root Tests.

ISBN 87-7882-012-X (print); ISBN 87-7882-013-8 (online).

WP 04-16 Anders U. Poulsen and Jonathan H.W. Tan: Can Information Backfire? Experimental Evidence from the Ultimatum Game. ISBN 87-7882-014-6 (print); ISBN 87-7882-015-4 (online).

WP 04-17 Werner Roeger and Frédéric Warzynski: A Joint Estimation of Price-Cost Margins and Sunk Capital: Theory and Evidence from the European Electricity Industry.

ISBN 87-7882-016-2 (print); ISBN 87-7882-017-0 (online). 
WP 04-18 Nabanita Datta Gupta and Tor Eriksson: New workplace practices and the gender wage gap.

ISBN 87-7882-018-9 (print); ISBN 87-7882-019-7 (online).

WP 04-19 Tor Eriksson and Axel Werwatz: The Prevalence of Internal Labour Markets - New Evidence from Panel Data.

ISBN 87-7882-020-0 (print); ISBN 87-7882-021-9 (online).

WP 04-20 Anna Piil Damm and Michael Rosholm: Employment Effects of Dispersal Policies on Refugee Immigrants: Empirical Evidence. ISBN 87-7882-022-7 (print); ISBN 87-7882-023-5 (online).

2005:

WP 05-1 Anna Piil Damm and Michael Rosholm: Employment Effects of Dispersal Policies on Refugee Immigrants: Theory.

ISBN 87-7882-024-3 (print); ISBN 87-7882-025-1 (online).

WP 05-2 Anna Piil Damm: Immigrants’ Location Preferences: Exploiting a Natural Experiment.

ISBN 87-7882-036-7 (print); ISBN 87-7882-037-5 (online).

WP 05-3 Anna Piil Damm: The Danish Dispersal Policy on Refugee Immigrants 1986-1998: A Natural Experiment? ISBN 87-7882-038-3 (print); ISBN 87-7882-039-1 (online).

WP 05-4 Rikke Ibsen and Niels Westergaard-Nielsen: Job Creation and Destruction over the Business Cycles and the Impact on Individual Job Flows in Denmark 1980-2001.

ISBN 87-7882-040-5 (print); ISBN 87-7882-041-3 (online).

WP 05-5 Anna Maria Kossowska, Nina Smith, Valdemar Smith and Mette Verner: Til gavn for bundlinjen - Forbedrer kvinder i topledelse og bestyrelse danske virksomheders bundlinje?

ISBN 87-7882-042-1 (print); ISBN 87-7882-043-X (online).

WP 05-6 Odile Poulsen and Gert Tinggaard Svendsen: The Long and Winding Road: Social Capital and Commuting.

ISBN 87-7882-044-8 (print); ISBN 87-7882-045-6 (online).

WP 05-7 Odile Poulsen and Gert Tinggaard Svendsen: Love Thy Neighbor: Bonding versus Bridging Trust.

ISBN 87-7882-062-6 (print); ISBN 87-7882-063-4 (online). 
WP 05-8 Christian Bjørnskov: Political Ideology and Economic Freedom. ISBN 87-7882-064-2 (print); ISBN 87-7882-065-0 (online).

WP 05-9 Sebastian Buhai and Coen Teulings: Tenure Profiles and Efficient Separation in a Stochastic Productivity Model. ISBN 87-7882-066-9 (print); ISBN 87-7882-067-7 (online).

WP 05-10 Christian Grund and Niels Westergård-Nielsen: Age Structure of the Workforce and Firm Performance.

ISBN 87-7882-068-5 (print); ISBN 87-7882-069-3 (online).

WP 05-11 Søren Harck: AD-AS på dansk.

ISBN 87-7882-070-7 (print); ISBN 87-7882-071-5 (online).

WP 05-12 Søren Harck: Hviler Dansk Økonomi på en Cobb-Douglas teknologi?

ISBN 87-7882-092-8 (print); ISBN 87-7882-093-6 (online).

2006:

WP 06-1 Nicolai Kristensen and Edvard Johansson: New Evidence on Cross-Country Differences in Job Satisfaction Using Anchoring Vignettes.

ISBN 87-7882-094-4 (print); ISBN 87-7882-095-2 (online).

WP 06-2 Christian Bjørnskov: How Does Social Trust Affect Economic Growth?

ISBN 87-7882-096-0 (print); ISBN 87-7882-097-9 (online).

WP 06-3 Jan Bentzen, Erik Strøjer Madsen and Valdemar Smith: The Growth Opportunities for SMEs?

ISBN 87-7882-098-7 (print); ISBN 87-7882-099-5 (online).

WP 06-4 Anna Piil Damm: Ethnic Enclaves and Immigrant Labour Market Outcomes: Quasi-Experimental Evidence. ISBN 87-7882-100-2 (print); ISBN 87-7882-101-0 (online).

WP 06-5 Svend Jespersen, Nicolai Kristensen og Lars Skipper: En kritik af VEU-udvalgets arbejde.

ISBN 87-7882-159-2 (print); ISBN 87-7882-160-6 (online).

WP 06-6 Kræn Blume and Mette Verner: Welfare Dependency among Danish Immigrants.

ISBN 87-7882-161-4 (print); ISBN 87-7882-162-2 (online). 
WP 06-7 Jürgen Bitzer, Wolfram Schrettl and Philipp J.H. Schröder: Intrinsic Motivation versus Signaling in Open Source Software Development. ISBN 87-7882-163-0 (print); ISBN 87-7882-164-9 (online).

WP 06-8 Valérie Smeets, Kathryn Ierulli and Michael Gibbs: Mergers of Equals \& Unequals.

ISBN 87-7882-165-7 (print); ISBN 87-7882-166-5 (online).

WP 06-9 Valérie Smeets: Job Mobility and Wage Dynamics.

ISBN 87-7882-167-3 (print); ISBN 87-7882-168-1 (online).

WP 06-10 Valérie Smeets and Frédéric Warzynski: Testing Models of Hierarchy: Span of Control, Compensation and Career Dynamics.

ISBN 87-7882-187-8 (print); ISBN 87-7882-188-6 (online).

WP 06-11 Sebastian Buhai and Marco van der Leij: A Social Network Analysis of Occupational Segregation.

ISBN 87-7882-189-4 (print); ISBN 87-7882-190-8 (online).

2007:

WP 07-1 Christina Bjerg, Christian Bjørnskov and Anne Holm: Growth, Debt Burdens and Alleviating Effects of Foreign Aid in Least Developed Countries.

ISBN 87-7882-191-6 (print); ISBN 87-7882-192-4 (online).

WP 07-2 Jeremy T. Fox and Valérie Smeets: Do Input Quality and Structural Productivity Estimates Drive Measured Differences in Firm Productivity?

ISBN 87-7882-193-2 (print); ISBN 87-7882-194-0 (online).

WP 07-3 Elisabetta Trevisan: Job Security and New Restrictive Permanent Contracts. Are Spanish Workers More Worried of Losing Their Job?

ISBN 87-7882-195-9 (print); ISBN 87-7882-196-7 (online).

WP 07-4 Tor Eriksson and Jaime Ortega: Performance Pay and the "Time Squeeze”.

ISBN 9788778822079 (print); ISBN 9788778822086 (online). 
WP 07-5 Johan Moritz Kuhn: My Pay is Too Bad (I Quit). Your Pay is Too Good (You're Fired).

ISBN 9788778822093 (print); ISBN 9788778822109 (online).

WP 07-6 Christian Bjørnskov: Social trust and the growth of schooling. ISBN 9788778822116 (print); ISBN 9788778822123 (online).

WP 07-7 Jan Bentzen and Valdemar Smith: Explaining champagne prices in Scandinavia - what is the best predictor?

ISBN 9788778822130 (print); ISBN 9788778822147 (online).

WP 07-8 Sandra Cavaco, Jean-Michel Etienne and Ali Skalli: Identifying causal paths between health and socio-economic status:

Evidence from European older workforce surveys ISBN 9788778822154 (print); ISBN 9788778822161 (online).

WP 07-9 Søren Harck: Long-run properties of some Danish macroeconometric models: an analytical approach.

ISBN 9788778822390 (print); ISBN 9788778822406 (online).

WP 07-10 Takao Kato and Hideo Owan: Market Characteristics, Intra-Firm Coordination, and the Choice of Human Resource Management Systems: Evidence from New Japanese Data.

ISBN 9788778822413 (print); ISBN 9788778822420 (online).

WP 07-11 Astrid Würtz: The Long-Term Effect on Children of Increasing the Length of Parents' Birth-Related Leave.

ISBN 9788778822437 (print); ISBN 9788778822444 (online).

WP 07-12 Tor Eriksson and Marie-Claire Villeval: Performance Pay, Sorting and Social Motivation.

ISBN 9788778822451 (print); ISBN 9788778822468 (online).

WP 07-13 Jane Greve: Obesity and Labor Market Outcomes: New Danish Evidence.

ISBN 9788778822475 (print); ISBN 9788778822482 (online).

2008:

WP 08-1 Sebastian Buhai, Miguel Portela, Coen Teulings and Aico van Vuuren: Returns to Tenure or Seniority ISBN 9788778822826 (print); ISBN 9788778822833 (online). 
WP 08-2 Flora Bellone, Patrick Musso, Lionel Nesta et Frédéric Warzynski: L'effet pro-concurrentiel de l'intégration européenne : une analyse de l'évolution des taux de marge dans les industries manufacturières françaises ISBN 9788778822857 (print); ISBN 9788778822864 (online).

WP 08-3 Erdal Yalcin: The Proximity-Concentration Trade-Off under Goods Price and Exchange Rate Uncertainty ISBN 9788778822871 (print); ISBN 9788778822888 (online)

WP 08-4 Elke J. Jahn and Herbert Brücker: Migration and the Wage Curve: A Structural Approach to Measure the Wage and Employment Effects of Migration ISBN 9788778822895 (print); ISBN 9788778822901 (online)

WP 08-5 Søren Harck: A Phillips curve interpretation of error-correction models of the wage and price dynamics

ISBN 9788778822918 (print); ISBN 9788778822925 (online)

WP 08-6 Elke J. Jahn and Thomas Wagner: Job Security as an

Endogenous Job Characteristic

ISBN 9788778823182 (print); ISBN 9788778823199 (online)

WP 08-7 Jørgen Drud Hansen, Virmantas Kvedaras and Jørgen UlffMøller Nielsen: Monopolistic Competition, International Trade and Firm Heterogeneity - a Life Cycle Perspective ISBN 9788778823212 (print); ISBN 9788778823229 (online)

WP 08-8 Dario Pozzoli: The Transition to Work for Italian University Graduates ISBN 9788778823236 (print); ISBN 9788778823243 (online)

WP 08-9 Annalisa Cristini and Dario Pozzoli: New Workplace Practices and Firm Performance: a Comparative Study of Italy and Britain ISBN 9788778823250 (print); ISBN 9788778823267 (online)

WP 08-10 Paolo Buonanno and Dario Pozzoli: Early Labour Market Returns to College Subjects ISBN 9788778823274 (print); ISBN 9788778823281 (online)

WP 08-11 Iben Bolvig: Low wage after unemployment - the effect of changes in the UI system ISBN 9788778823441 (print); ISBN 9788778823458 (online) 
WP 08-12 Nina Smith, Valdemar Smith and Mette Verner: Women in Top Management and Firm Performance

ISBN 9788778823465 (print); ISBN 9788778823472 (online)

WP 08-13 Sebastian Buhai, Elena Cottini and Niels Westergård-Nielsen: The impact of workplace conditions on firm performance ISBN 9788778823496 (print); ISBN 9788778823502 (online)

WP 08-14 Michael Rosholm: Experimental Evidence on the Nature of the Danish Employment Miracle ISBN 9788778823526 (print); ISBN 9788778823533 (online)

WP 08-15 Christian Bjørnskov and Peter Kurrild-Klitgaard: Economic Growth and Institutional Reform in Modern Monarchies and Republics: A Historical Cross-Country Perspective 1820-2000 ISBN 9788778823540 (print); ISBN 9788778823557 (online)

WP 08-16 Nabanita Datta Gupta, Nicolai Kristensen and Dario Pozzoli: The Validity of Vignettes in Cross-Country Health Studies ISBN 9788778823694 (print); ISBN 9788778823700 (online)

WP 08-17 Anna Piil Damm and Marie Louise Schultz-Nielsen: The Construction of Neighbourhoods and its Relevance for the Measurement of Social and Ethnic Segregation: Evidence from Denmark ISBN 9788778823717 (print); ISBN 9788778823724 (online)

WP 08-18 Jørgen Drud Hansen and Jørgen Ulff-Møller Nielsen: Price as an Indicator for Quality in International Trade? ISBN 9788778823731 (print); ISBN 9788778823748 (online)

WP 08-19 Elke J. Jahn and Thomas Wagner: Do Targeted Hiring Subsidies and Profiling Techniques Reduce Unemployment? ISBN 9788778823755 (print); ISBN 9788778823762 (online)

WP 08-20 Flora Bellone, Patrick Musso, Lionel Nesta and Frederic Warzynski: Endogenous Markups, Firm Productivity and International Trade: Testing Some Micro-Level Implications of the Melitz-Ottaviano Model ISBN 9788778823779 (print); ISBN 9788778823786 (online) 
WP 08-21 Linda Bell, Nina Smith, Valdemar Smith and Mette Verner: Gender differences in promotion into top-management jobs ISBN 9788778823830 (print); ISBN 9788778823847(online)

WP 08-22 Jan Bentzen and Valdemar Smith: An empirical analysis of the relationship between the consumption of alcohol and liver cirrhosis mortality ISBN 9788778823854 (print); ISBN 9788778823861(online)

WP 08-23 Gabriel J. Felbermayr, Sanne Hiller and Davide Sala: Does Immigration Boost Per Capita Income?

ISBN 9788778823878 (print); ISBN 9788778823885 (online)

WP 08-24 Christian Gormsen: Anti-Dumping with Heterogeneous Firms: New Protectionism for the New-New Trade Theory ISBN 9788778823892 (print); ISBN 9788778823908 (online)

WP 08-25 Andrew E. Clark, Nicolai Kristensen and Niels WestergårdNielsen: Economic Satisfaction and Income Rank in Small Neighbourhoods ISBN 9788778823915 (print); ISBN 9788778823922 (online)

WP 08-26 Erik Strøjer Madsen and Valdemar Smith: Commercialization of Innovations and Firm Performance ISBN 9788778823939 (print); ISBN 9788778823946 (online)

WP 08-27 Louise Lykke Brix and Jan Bentzen: Waste Generation In Denmark 1994-2005

An Environmental And Economic Analysis ISBN 9788778823953 (print); ISBN 9788778823977 (online)

WP 08-28 Ingo Geishecker, Jørgen Ulff-Møller Nielsen and Konrad Pawlik: How Important is Export-Platform FDI? Evidence from Multinational Activities in Poland ISBN 9788778823984 (print); ISBN 9788778823991 (online)

WP 08-29 Peder J. Pedersen and Mariola Pytlikova: EU Enlargement: Migration flows from Central and Eastern Europe into the Nordic countries - exploiting a natural experiment ISBN 9788778824004 (print); ISBN 9788778824028 (online) 
2009:

WP 09-1 Tomi Kyyrä, Pierpaolo Parrotta and Michael Rosholm: The Effect of Receiving Supplementary UI Benefits on Unemployment Duration ISBN 9788778824035 (print); ISBN 9788778824042 (online)

WP 09-2 Dario Pozzoli and Marco Ranzani: Old European Couples' Retirement Decisions: the Role of Love and Money ISBN 9788778824165 (print); ISBN 9788778824172 (online)

WP 09-3 Michael Gibbs, Mikel Tapia and Frederic Warzynski: Globalization, Superstars, and the Importance of Reputation: Theory \& Evidence from the Wine Industry ISBN 9788778824189 (print); ISBN 9788778824196 (online)

WP 09-4 Jan De Loecker and Frederic Warzynski: Markups and FirmLevel Export Status ISBN 9788778824202 (print); ISBN 9788778824219 (online)

WP 09-5 Tor Eriksson, Mariola Pytliková and Frédéric Warzynski: Increased Sorting and Wage Inequality in the Czech Republic: New Evidence Using Linked Employer-Employee Dataset ISBN 9788778824226 (print); ISBN 9788778824233 (online)

WP 09-6 Longhwa Chen and Tor Eriksson: Vacancy Duration, Wage Offers, and Job Requirements - Pre-Match Data Evidence ISBN 9788778824240 (print); ISBN 9788778824257 (online)

WP 09-7 Tor Eriksson, Valérie Smeets and Frédéric Warzynski: Small Open Economy Firms in International Trade: Evidence from Danish Transactions-Level Data ISBN 9788778823861 (print); ISBN 9788778823878 (online)

WP 09-8 Dario Pozzoli and Marco Ranzani: Participation and Sector Selection in Nicaragua ISBN 9788778823885 (print); ISBN 9788778823892 (online)

WP 09-9 Rikke Ibsen, Frederic Warzynski and Niels Westergård-Nielsen: Employment Growth and International Trade: A Small Open Economy Perspective ISBN 9788778823908 (print); ISBN 9788778823915 (online) 
WP 09-10 Roger Bandick and Holger Görg: Foreign acquisition, plant survival, and employment growth

ISBN 9788778823922 (print); ISBN 9788778823939 (online)

WP 09-11 Pierpaolo Parrotta and Dario Pozzoli: The Effect of Learning by Hiring on Productivity

ISBN 9788778823946 (print); ISBN 9788778823953 (online)

WP 09-12 Takao Kato and Pian Shu

Peer Effects, Social Networks, and Intergroup

Competition in the Workplace

ISBN 9788778823984 (print); ISBN 9788778823991 (online)

WP 09-13 Sanne Hiller and Erdal Yalcin: Switching between Domestic Market Activity, Export and FDI

ISBN 9788778824004 (print); ISBN 9788778824028 (online)

WP 09-14 Tor Eriksson and Mariola Pytlikova: Foreign Ownership Wage Premia in Emerging Economies: Evidence from Czech Republic ISBN 9788778824035 (print); ISBN 9788778824042 (online)

WP 09-15 Astrid Würtz Rasmussen: Family Structure Changes and Children's Health, Behavior, and Educational Outcomes ISBN 9788778824059 (print); ISBN 9788778824066 (online)

WP 09-16 Tor Eriksson: How Many Danish Jobs Can (Potentially) Be Done Elsewhere? ISBN 9788778824073 (print); ISBN 9788778824080 (online)

WP 09-17 Lorenzo Cappellari, Claudio Lucifora and Dario Pozzoli: Determinants of Grades in Maths for Students in Economics ISBN 9788778824103 (print); ISBN 9788778824110 (online) 